\section{Revolution in references: give readers a chance by putting page numbers}

Sir - In On the Origin of Species, Charles Darwin observed that Malthus's doctrine applied to the animal and vegetable kingdoms. I am a lawyer who recently published a book that required me to analyse hundreds of scientific books (including Darwin's Origin), book chapters and articles. In nearly all, a citation to this fact would read this way: "Darwin, C. (1859). On the Origin of Species. London: John Murray". Unless readers sleuthed through the entire 490-page book, they would have had to take my word for what Darwin said. The problem was nearly as bad for citations to articles. Standard scientific notation does not appear to require page references for citations, though sometimes quotations get them.

I was surprised by this practice. Standard legal writing requires authors to provide the pages on which they rely for a proposition. It doesn't matter whether the source is a two-page letter or a thousandpage book. That way readers can easily locate the proposition cited.

I have spent hours, even days, sifting scientific articles and books for referenced material. Once I found a citation to a proposition so unusual and pertinent that I purchased the book and read the entire thing. When I failed to locate the cited proposition, I read the book again. Still unable to find it, I tracked down the author and begged her to give me the page numbers. With apologies, she admitted that what I sought was not in the book.

Before me is a book chapter I have written, to be published by a scientific press. When I turned it in to the publisher, I gave footnotes citing the pages at which every proposition upon which I relied could be found. I was informed that this is not good scientific notation. The publisher returned the chapter with instructions for me to go through each footnote and delete the offending references to the exact pages.

What is going on? A physicist friend says that some colleagues aim to outline their achievements while giving away as little as possible to competitors. A primatologist friend believes that scientific specialization is now so common that scientists write only for colleagues in their disciplines, who can be assumed to have read everything that the author has.

Perhaps scientists are simply too busy and trusting to cross-check their colleague's claims. But as a legal outsider peering into the scientific world, I appeal to the instinct of the scientist for precision and accuracy. Require, or at least permit, page references to cited material. And stop driving me crazy. (NB: the Malthus observation is found on page 63 of the first edition.) Steve Wise

Wise \& Slater-Wise, P.C., 896 Beacon Street, Suite 303, Boston, Massachusetts 02215, USA

The Editor replies-Nature now requires authors citing a section of a stand-alone text (for example a book or thesis) to provide the number(s) of the cited pages. Authors need not provide numbers for cited pages within papers and other articles, although they should continue, as now, to provide the first and last page numbers of the whole article.

\section{Bridging the quality gap}

Sir-Between 1975 and May 2000, a total of 330 science and technology papers with at least one author from the University of Botswana (the only university in the country) have been published in journals with an SCI impact factor. Of these, $90 \%$ have been cited fewer than five times and $54 \%$ have never been cited (excluding self or co-author citations). The average number of citations per paper is 1.95. The current rate of publication averages one impact-factored paper per academic staff member every three to five years. These figures represent the bulk of the country's scientific output. Why is research productivity and impact so low?

Botswana is one of the more prosperous countries in the region, but the university offers little opportunity for good research. It is usually published in journals without impact factors and in conference proceedings. Until recently, few researchers seemed aware of the use of impact factors and citation analyses. However, with the equalizing effect of the Internet and ready access to abstracting journals and citation databases, we should become more active participants in quality research.

Developed countries can help others to raise the impact of their research and to bridge the quality gap. Instead of viewing postgraduates from developing countries as a short-term source of money, Western universities should see their training as a long-term contract to stimulate research and maintain collaboration once their overseas visitors are back in post.

Most $\mathrm{PhD}$ graduates in developed countries do postdoctoral stints to hone their research skills. $\mathrm{PhD}$ graduates from the Third World generally return to their own country as fully fledged lecturers with all the associated demands of teaching and administration, hence removing them from significant research activity.

Part of the problem is that senior administrators at universities in developing countries seldom have scientific backgrounds and do not appreciate what it takes to do good science. A compounding problem is that - unlike the situation in developed countries, where scientists are trained and then recruited into academic institutions - in many developing countries staff are recruited as BSc graduates and then trained. Their early promise may not be realized. Universities in developed countries that train them seem willing to compromise standards, under pressure from their governments to increase income. Some Western academics apply double standards when asked, as part of an external peer-review process, to assess applicants for promotion in developingworld universities — recommending people they admit would not meet the criteria of the Western institution.

Every country has the capacity to contribute to the body of scientific knowledge. But for developing countries, without appropriate incentives and assistance from within and without, the quality gap will continue to widen. Indra Riddoch

Faculty of Agriculture, University of Botswana, Private Bag 0027, Gaborone, Botswana

\section{The public has (rightly) lost faith in scientists}

Sir - The mishandling of BSE (Nature $408,1 \& 5 ; 2000)$ is not due to political or commercial interference in research. It is due to the failure of British scientists to live up to the traditional ethical standards of empirical science. In this, they are no worse than scientists in the United States.

Scientists everywhere have become dependent on governments and multinational corporations for funding. There still are scientists who live up to their responsibilities to serve the public, but they are now a powerless minority among those who call themselves 'scientists' because of their paper credentials.

If genuine scientists had not been an impotent minority, the British politicians and the commercial interests that pressured the politicians would have recognized the dangers of a public backlash from their actions.

As things turned out, the British public has so little faith in science that the current 'righteous indignation' of scientists fails to arouse very much public indignation. Concerned citizens no longer expect scientists to act to protect their health and safety. The public realizes it has to protect itself, with little help from scientists.

\section{Irwin D. Bross}

Biomedical Metatechnology Inc., 109 Maynard

Drive, Amherst, New York 14226, USA 